\title{
Knowledge Management to Support Supply Chain Sustainability and Collaboration Practices
}

\author{
Marianne Gloet \\ University of Melbourne \\ marianne.gloet@unimelb.edu.au
}

\author{
Danny Samson \\ University of Melbourne \\ d.samson@unimelb.edu.au
}

\begin{abstract}
This exploratory research examined the contribution of knowledge management (KM) to sustainability and collaboration practices across a number of small to medium size Australian food and beverage exporters. A growing focus on sustainable supply chain management (SSCM) in global supply chains offers opportunities for organizations to create value and secure competitive advantage by employing strategic KM practices to support SSCM. Analysis of eight case study organizations revealed that KM contributes to SSCM across a number of areas, including strategic focus, protecting firm reputation and performance, risk management, innovation, collaboration and relationships with partners.
\end{abstract}

\section{Introduction}

This paper investigates the ways in which knowledge management contributes to sustainability and stakeholder collaboration across a number of small to medium size Australian food and beverage exporters. The contemporary push for sustainability is driven by consumers, government and other stakeholders, and this is a key aspect of food export supply chains. Today the world's food production and consumption is characterized by significant increases in imports and exports, global sourcing of products and a broader global scope overall. Sustainability may be a significant source of competitive advantage; by engaging in sustainable supply chain management practices, organizations and their supply chains may be more attractive to a wide range of stakeholders [1]

The globalization of food markets has increased scrutiny relating to the sources of food, quality, provenance and ethical issues related to sourcing [2]. A much greater level of attention is now paid to the origins and production methods of food and related products across the food supply chain. Issues such as food quality, food safety, traceability, use of pesticides and other sustainability related issues are now in the forefront of stakeholder concerns about food supply chains. There is a need for food producers to respond to changing consumer demands for increased sustainability of food products and food processing [3], as well as assuring traceability, through packaging, labelling and logos [4]. Along with globalization, the increased complexity of modern supply chains raises new questions about the nature and type of collaboration that can support sustainability across food export chains.

The growth of the food export trade in Australia has grown significantly in recent decades. Australia is a net exporter of food and agribusiness products and currently exports over half of its agricultural products. The value of Australian exports in the food and agribusiness sector has grown by over $6 \%$ per annum over the last ten years and was worth $\$ 40.8$ billion in 2015 [5] (Government of Australia, 2018). This paper is significant because it is the first time that the links between KM, sustainability strategy and collaboration have been investigated in the context of food and beverage exporters from Australia.

\section{Literature Review}

The strategic management of supply chains has the potential to deliver value to customers and other stakeholders, as opposed to simply providing inputs, goods or services [6]. Particularly from a resourcebased theory perspective, supply chains have the potential to generate value and thus contribute to sustained competitive advantage [7]. Modern supply chain management (SCM) is undergoing major changes, as global markets become more turbulent and competitive as product and service life-cycles shorten, thus creating greater uncertainty and potential risk. As a result the strategic potential of effective SCM has never been greater [8][9][10]. However, SCM involves many layers of complexity, including crossborder flows of goods, services, investment, as well as intellectual and human capital that provide challenges at the management level [11]. Growing pressure from customers and other stakeholders to support 
sustainability in supply chains means that these challenges are considerably amplified. It is clear that the strategic management of supply chains can create value for customers and other stakeholders; however, the success of creating sustainable competitive advantage in SCM is highly dependent on knowledge and the extent to which it is effectively managed [12].

The past two decades have seen a growing focus on sustainable development, which has had an impact on supply chain management (SCM) as firms try to determine the various ways sustainability can be supported across their business functions. Given that SCM often accounts for the majority of external expenditure in many organizations [13], there is significant potential for SCM to contribute to sustainability in a number of different ways. Indeed, many organizations are revisiting their SCM operations as they become aware of the ways in which a greater focus on social and environmental responsibility can lead to a range of positive outcomes. Traditional SCM approaches of the past have tended to focus on financial outcomes without much consideration for environmental or social and community concerns. For instance, Simchi-Levi et al. (2011) define SCM as "a set of approaches to integrate supply chain participants so that products are produced and distributed at the right quantities, to the right locations and at the right time to ensure the total cost is minimized and the service level is maximized" [14]. This definition clearly emphasizes the strong focus on economic performance which is characteristic of traditional SCM.

However, a wide range of literature focusing on sustainable supply chain management (SSCM) over the past two decades has challenged traditional SCM practices linked only to economic performance, focusing on sustainability from a combined focus on economic, environmental and social issues [15] [16] [17] [18] [1] [19] Although many definitions can be found in the literature, Seuring \& Muller (2008) define SSCM as "the management of material, information and capital flows as well as cooperation among companies along the supply chain while taking goals from all three dimensions of sustainable development, i.e., economic, environmental and social, into account which are derived from customer and stakeholder requirements" [16]. This shift reflects an increasing interest in corporate social responsibility (CSR) as a means of supporting performance across the three 'pillars' of economic, environmental and social issues [20]. SSCM represents a broader scope of responsibilities and practice from a SCM point of view and encourages organizations to consider the impact of their business strategy and practices on the environment, consumers, employees, communities and other stakeholders [21]. However, research on SSCM is still dominated by a focus on economic performance and to an increasing extent, the environmental dimension of sustainability, while social dimensions of sustainability still lag behind in coverage.

The economic dimension of sustainability focuses on practices such as generating profit, cash flow and return on investment that contribute to bottom line performance [15]. In terms of SCM this generates a focus on creating competitive advantage and value through cost, quality, speed and flexibility [22]. Environmentally focused SSCM practices can include supplier selection, supplier development, logistics options, location decisions, or packaging choices [19]. Other operational issues might include energy use, green procurement, the disposal of hazardous materials, environmentally friendly disposal or reverse logistics [23] [24] [25].

The social dimension of SSCM takes into consideration a wide range of practices, including community-focused issues, corporate governance, human rights, diversity, employee relations, safety and ethics [26] [27]. The social dimension also includes supporting activities or practices in the value chain such as development of technology to support procurement, such as purchasing from minorityowned suppliers or fair-trade sources, as well as ensuring safe and humane working conditions in supplier plants [1] [28] [29] [30].

More recently, a new debate has emerged that suggests a new approach to sustainability is needed in order to progress sustainability efforts to a higher level [31]. Markman and Krause [32] take the view that currently no businesses are "truly or fully sustainable" and suggest a way forward through a new paradigm of sustainable practices. In this paradigm, any business activity, including SSCM, must contribute to ecological health, maintain ethical standards on behalf of social justice and deliver economic improvements. Moreover, environmental concerns should be prioritized above all other issues, followed by social concerns, and lastly the economic dimension.

This view is supported by Montabon et. al. [33] who argue that economic outcomes continue to be prioritized in SSCM approaches, and that research in the area of SSCM is also underpinned by instrumental logics that do not support sustainability in supply chains. They propose the development of an ecologically dominant logic with the central premise being that tradeoffs will have to occur in order for supply chains to be fully sustainable. This ecologically dominant logic considers the environment first, followed by social concerns, then economic 
performance. Only when ecologically dominated logic prevails will supply chains be genuinely sustainable.

\subsection{Knowledge Management and SCM}

It is well recognized that knowledge is a strategic resource in modern supply chains [34]. As such KM is a fundamental enabler of SCM in global environments that are both information and knowledge intensive. In today's turbulent and highly competitive environments, SCs can be regarded as configurations of firms with an ongoing need to develop flexibility, agility and capabilities in order to maintain their competitive edge. Successful SCM involves the ability to quickly utilize and mobilize the entire network of suppliers, vendors, buyers and customers through innovative trade-offs and flexible business models. $\mathrm{KM}$ can play a substantial role in such networks, since flows of information and knowledge are paramount to processes such as coordination and collaboration, and knowledge-based tools can form a significant part of SCM capabilities [35].

The role of KM in SCM reflects a rapidly growing area of academic and managerial interest. Bhosale and Kant's (2016) extensive literature review of KM and SCM over the years 2001-2015, identifies main areas of research interest in KM in SCM [36]. Major KM issues relating to SCM focused on knowledge processes such as knowledge acquisition, knowledge sharing/transfer knowledge integration, knowledge protection, knowledge innovation and knowledge dissemination. Their study also revealed that predominant SCM issues included the effect of $\mathrm{KM}$ on SC performance, SC relationships, SC integration, product innovation, IT in SC, SC collaboration, and SC networks. Their study reflects a broad range of issues linking $\mathrm{KM}$ and $\mathrm{SCM}$, demonstrating from a $\mathrm{KM}$ perspective the ways in which $\mathrm{KM}$ contributes to effective and strategic SCM. More than $90 \%$ of the articles they include in their literature review were published between 2006-2014, thus indicating that the links between KM and SCM represent a growing area of interest. Another review of literature by Marra et. al. [37] indicated that KM plays an important role in implementing SCM., such as in knowledge capture, knowledge organization, knowledge integration, and for improving collaboration.

There is a broad base of literature concerning KM processes such as knowledge acquisition, knowledge transfer and sharing, as well as knowledge dissemination and their contribution to SCM. Supported by KM, data capture, information mining and knowledge acquisition in SCM can increase an organization's ability to adjust to changes in the environment [38]. Pan et al. [39] consider knowledge sharing, knowledge transfer, knowledge creation and learning to be the main KM activities related to SCM. In their view, the key to success of KM activities is being able to capture knowledge effectively and to transfer knowledge into new products, services and technologies. Other research found that KM processes such as knowledge acquisition and dissemination lead to higher levels of performance in buyer-supplier collaborations [40]. Cai et al. [41] point to the role of $\mathrm{KM}$ in enhancing knowledge sharing, particularly with respect to issues of power and the mediation of trust in SC relationships. Other research emphasizes the importance of knowledge sharing and re-use in SCM [42]. The identification, modelling and explicit representation of knowledge can support knowledge sharing and collaboration by developing a supply chain wide knowledge ontology and vocabulary - a commonly understood language around knowledge [43]. In terms of SC collaboration, Cao et al. [44] found that collaboration involves creating ideas and value together - rather than merely exchanging information - and this is an area where KM can add value though knowledge development and good communication. Another study found that knowledge sharing and enrichment activities can lead to enterprise-wide knowledge integration in collaborative SCs [45].

\section{Methodology}

Two complementary theoretical perspectives - the resource based view (RBV) and the knowledge based view $(\mathrm{KBV})$ - underpin and support this study. In both the RBV and the KBV, resources at the base of a firm's capabilities provide the foundation for competitive advantage. Following the RBV, knowledge is considered an essential resource within organizations [46] [47], and success is dependent on the ways in which firms develop and deploy their knowledge resources and capabilities [48] [49] [50]. Similarly, in the KBV, knowledge is regarded as the key resource, where the creation, integration and application of knowledge is at the core of the firm, stressing the role of knowledge in developing organizational capabilities to create sustainable competitive advantage [51] [52] [53]. Given that the RBV and the KBV take a holistic view across business functions in a firm, they are well suited to the study of complex phenomena such as knowledge management.

This study adopts a qualitative cross-case analysis methodology using eight detailed case studies of Australian food and beverage producers and manufacturers. These small to medium enterprises (SMEs) consisted of Australian companies in the food and drink sector who have developed successful 
domestic and overseas export supply chains. All export award winners in the fresh food agri-business area in Australia, these companies claim a strong commitment to sustainability and a network of robust relationships with various stakeholders such as partners and customers overseas (see Table 1).

Although sometimes criticized for having a lack of reliability, the legitimacy of case studies is enhanced when the subject matter has indistinct boundaries and varying contexts, such as in this study. A careful selection of appropriate cases increases their reliability. Recognizing the importance of the initial selection of a case to improve reliability [54], the cases were selected as part of a purposive sampling methodology to ensure we learned the most possible from this exploratory research. Hence we searched for Australian companies that had all developed a strong reputation for export success and who were actively engaged in growing new markets overseas. In most cases, these firms had won awards such as 'Exporter of the Year' at the federal or state level (see Table 1). They also demonstrated sound KM practices across their operations. The main research question underpinning the study concerned the ways in which KM contributes toward sustainability and collaboration in the case study organizations.

\begin{tabular}{|c|l|l|}
\hline $\begin{array}{c}\text { Case } \\
\text { code }\end{array}$ & \multicolumn{1}{|c|}{ Business Type } & \multicolumn{1}{|c|}{ Location } \\
\hline 1 & Cherries; apples & Tasmania \\
\hline 2 & $\begin{array}{l}\text { Carrots; onions; other fresh } \\
\text { vegetables }\end{array}$ & Western Australia \\
\hline 3 & Honey and honey products & Tasmania \\
\hline 4 & $\begin{array}{l}\text { Salmon; trout; processed } \\
\text { fish products }\end{array}$ & Tasmania \\
\hline 5 & Whisky; whisky liqueurs & Tasmania \\
\hline 6 & $\begin{array}{l}\text { Fresh truffles; truffle } \\
\text { products }\end{array}$ & Western Australia \\
\hline 7 & Whisky; gin & Tasmania \\
\hline 8 & Abalone & South Australia \\
\hline
\end{tabular}

Table 1. Case study participants

A case study methodology was chosen for this study because case study research is highly appropriate in settings with a variety of overlapping contexts and discourses. The robustness of case study approaches is dependent on the careful selection of appropriate cases as well as the application of relevant case study principles and practices. Since eight organizations were involved in this study, we adopted a "cross-case analysis" approach, recommended by Miles and Huberman [55] for enhancing generalizability when investigating complex situations. The use of a cross-case analysis increases construct validity, reliability and generalizability of the findings. Yin [54] also asserts that multiple case designs result in substantially enhanced results compared with results from a single case design. Nevertheless, multiple case designs require structure and focus in order to synthesize data relating to the research questions into a succinct but cogent analysis. A content analysis technique analyzed data gathered through in-depth interviews with senior managers or owners, while a multiple cross-case study design tapped into their collective perceptions concerning their respective organization's approach or pathways to the management of their export supply chain.

\begin{tabular}{|c|c|}
\hline DIMENSION & ATTRIBUTES \\
\hline $\begin{array}{l}\text { Strategy } \\
\text { (focus on SC } \\
\text { management, triple } \\
\text { bottom line issues) } \\
\end{array}$ & $\begin{array}{l}\text { Strategic orientation/values prominent } \\
\text { Commitment to sustainability strategy } \\
\text { Balance between } \\
\text { environmental/social/economic goals }\end{array}$ \\
\hline $\begin{array}{l}\text { Continuity } \\
\text { (focus on long term } \\
\text { relationships) }\end{array}$ & $\begin{array}{l}\text { Partner development and selection } \\
\text { issues } \\
\text { Type/degree of interaction between SC } \\
\text { partners } \\
\text { Practices used to build long-term } \\
\text { relationships }\end{array}$ \\
\hline $\begin{array}{l}\text { Collaboration } \\
\text { (focus on partner } \\
\text { integration, } \\
\text { relationships and } \\
\text { communication) }\end{array}$ & $\begin{array}{l}\text { Technical and logistical integration of SC } \\
\text { partners } \\
\text { Joint development of new technology, } \\
\text { process and products } \\
\text { Nature of relationship/communication } \\
\text { processes }\end{array}$ \\
\hline $\begin{array}{l}\text { Risk } \\
\text { (focus on risk mitigation } \\
\text { activities to support } \\
\text { sustainability) }\end{array}$ & $\begin{array}{l}\text { Risk management processes, i.e. } \\
\text { monitoring suppliers, identifying partner } \\
\text { needs } \\
\text { Extent of standards/certification }\end{array}$ \\
\hline $\begin{array}{l}\text { Proactivity } \\
\text { (focus on active } \\
\text { engagement to support } \\
\text { sustainability) }\end{array}$ & $\begin{array}{l}\text { Learning from partners and other } \\
\text { sources } \\
\text { Protecting reputation or performance } \\
\text { Overall innovation capability } \\
\text { Commitment to SSCM practices such as } \\
\text { food safety, traceability }\end{array}$ \\
\hline
\end{tabular}

Table 2. Dimensions and Attributes of SSCM Practices

Given that this research was exploratory in nature, the purpose of this study was to generate a bank of rich data from which to identify major themes and subthemes [56], rather than offering generalizations based on quantitative analysis. The main challenges of multiple case study research involve issues of generalizability (construct validity) and reliability. Therefore, ensuring both validity and reliability in a multiple case study research is paramount. A properly designed case study protocol (CSP) is essential for research of this type [54]. The CSP includes a clear overview of the project, an accurate description of the field procedures and clear unambiguous research questions.

Using case study protocols recommended by Yin [54], a set of stem questions guided participant discussion during the interview. We applied a framework adapted from Beske et. al. [57] to 
investigate SSCM practices across five dimensions: 1) strategy; 2) continuity; 3) collaboration; 4) risk; and 5) proactivity (see Table 2). Specific research questions directed toward participants in the context of KM included a) the detailed nature of their SSCM practices; b) risk factors affecting sustainability efforts; c) extent of long-term relationships with clients and other stakeholders; d) extent of collaboration with SC partners on development of new technology, products and processes; e) degree of learning and innovation within the company.

\section{Findings and Discussion}

A number of issues were revealed as a result of the interviews with the eight case study companies, and yielded a broad range of information across their approaches to the nature and extent of their SSCM practices, strategic focus, innovation, collaboration and relationships. A summary of the case analyses follows below.

Case 1 - 'CherryCo' - This producer of super premium cherries, apples and cherry products in Tasmania exports cherries to over 20 countries across Europe, Asia and the Middle East. Their cherries are highly sought after in overseas markets due to their flavor, size and firmness which comes from being grown in ideal climate and biosecurity conditions found only in Tasmania. The company boasts a modern high-density cherry orchard which is netted to prevent damage from wind, birds and other native animals. Recently the company undertook a $\$ 3$ million upgrade of the packing shed and installed the latest grading technology to ensure that the fruit is packed and presented to consumers to highest quality standards. They have strong, enduring relationships with their Tier 1 customers to whom they guarantee supply. $80 \%$ of their annual crop is exported, and as part of their strategy, they mitigate risk by not selling all their export crop to China. Another risk mitigation strategy sees the company selling their products across different markets - typically split one third wholesale, one third online, and one third retail. A 5-year strategic plan with a strong commitment to sustainability underpins the business, and they have instituted many changes to supply chain design, security and traceability as well as strategies to prevent counterfeiting. Strong relationships with customers and trade associations are supported by regular travels to markets and customers overseas. Overall the KM and SSCM strategic focus is on quality, traceability, capacity, distribution and relationships.

Case 2 - 'CarrotCo' - Based in Western Australia, this company's premium product range includes cabbage, carrots, carrot concentrate, celery, onion, pumpkin, potatoes and olive products but by far the majority of the product is carrots and related products that are exported. In its packaging and processing operations the company uses advanced technology to quickly cool and safely and efficiently handle, store and distribute its products from the field to the customer. Trans-shipping done to the highest possible standard. Highly vertically integrated - they grow, pack and distribute their products. The strategic thrust of this organization focuses on building long term relationships with customers overseas. Maintaining supply consistency and stable pricing, even when markets are volatile, has resulted in successful collaboration with customers overseas. Ongoing innovation in areas such as processing, packing, cooling, quality control. The overall $\mathrm{KM}$ and SSCM focus is on technology (both process and product), quality, distribution, traceability and relationships.

Case 3 - 'HoneyCo' - This producer of premium honey and honey products located in northern Tasmania has won many overseas awards, including World's Best Honey. The company offers a diversified product range, including honey, mead, port, shipping of live bees and commercial pollination. Two thirds of their honey is exported, as overseas demand means they can command higher prices. China is their biggest customer, and the demand from Chinese consumers grows every year, and since Tasmanian honey is associated with both quality and safety, consumers are willing to pay premium prices. Excellent biosecurity controls in the areas as well as regular scientific testing of their products to ensure quality are cornerstones of their success. The business model is underpinned by a focus on investment in technology and innovative practices such as (transporting hives and developing, new honey extraction techniques. For a long time the company has recognized the need to develop long-term relationships with partners. As such they collaborate with a number of trusted partners overseas, as well as the Australian agency Austrade for contacts and promotion at trade shows overseas. Increasingly the company has seen a surge in tourist visits to their company and to the state to see in person the origin of the honey and to explore the provenance. The overall strategic focus on KM and SSCM is on provenance and traceability, quality, technology and innovation, as well as stakeholder relationships.

Case 4 - 'FishCo' - Located in Tasmania, this company are widely known producers of premium fresh salmon, trout and other value-added products, and are the largest vertically integrated salmon producer in Australia. With a state of the art processing facility and an extensive logistics infrastructure, the business model emphasizes the need to invest continually in R\&D in order to stay at the forefront of quality and innovation. This company is proud of its reputation for environmental sustainability and their strategy Important to develop strong brand awareness through 'playing on the back story', emphasizing the brand, its provenance and the commitment to environmental sustainability. They have even gone to court to protect their sustainability reputation and values. The company has developed a strong brand awareness, with an emphasis on provenance and traceability. They maintain a number of long standing relationships with customers overseas, and senior managers travel overseas regularly for face-to-face visits with customers. The company considers these relationships and personal contacts to be very important in Asian markets, as well as developing an understanding of cultural differences. The overall KM and SSCM strategic focus in this firm is on quality, sustainability, traceability, innovation, technology, and relationships. 
Case 5 - 'Whiskey1Co' - Located in northern Tasmania, this distillery has developed a sound imprint as a premium niche brand whisky and beverage producer, whose products include award winning whisky, whiskey liqueurs, vodka and pure distilled water. As a winner of many international awards that help to promote brand awareness, the company competes successfully in crowded market. A dedicated Visitors Centre and restaurant at the distillery welcomes 40,000 visitors a year, further promoting brand awareness and provenance associated with this pristine area of Tasmania. Senior managers, including the Head Distiller, travel overseas regularly to attend whisky fairs and trade shows, acting as ambassadors for Tasmania as a whisky making region and promoting its excellent provenance. The distillery have found that developing brand awareness means travelling to meet customers - as customers are interested in the 'DNA' of the product and its provenance. Over the years the company has developed an excellent overseas distribution network and many strong relationships strong relationships with overseas partners have gone a long way to ensuring success for the distillery. There is a strong commitment to a philosophy of continuous learning and improvement underpinning business practices. Success factors include having an appetite for risk, since export adds another level/dimension to the business. Strategic plans guide development of the business, and the predominant $\mathrm{KM} / \mathrm{SSCM}$ strategic focus is centered on quality, provenance, traceability and relationships.

\section{Case 6 - 'TruffleCo' -}

This company based in Western Australia exports truffles to 14 countries around the world, and has focused its branding and marketing to further the brand's imprint as being Australian in nature. Their strong provenance story builds brand awareness and commands a premium price for their products. In addition to exporting fresh truffles, TruffleCo has been highly innovative in developing a wide range of truffle based and truffle flavored products ranging from honey, aioli, butter, mustard, truffle sauce, salsa, and oils and these are attractively packaged in jars, bottles, and gift packs. Of the approximately one tonne of truffles that the company produces in an annual season, some are resold as fresh truffles, but the bulk of them are value added into products of which 14 different products are sold into retail markets and 7 different products are sold into food service markets. Key success factors in this business involve strong relationships, both up and down the supply chain, with both truffle suppliers and with customers and distributors. A lot of overseas travel is required, and the owner of TruffleCo seeks a culture fit with customers and distributors and a partner whose business is the right size. He carefully leads and manages his small but growing company and keeps a keen eye on cash flow and financial projections. One priority is to increase the firm's direct sales channel to about $15 \%$ of the business and they have developed the flexibility to produce to order, including supplying large customers such as McDonalds with a differentiated offering. The strategic focus of the company is focused on growing markets through offering a premium product range, developing bespoke products through application of innovative methods. The specific KM and SSCM focus includes issues such as traceability, quality, and relationships with partners, suppliers, distributors and customers along the supply chain.

Case 7 - Whisky2Co' -

When this company was established in 1994, there was no whisky business in Tasmania. It has now gained a reputation as a producer of one of the best whiskies in the world. Distilled by traditional methods and using only pure Tasmanian ingredients, each barrel is individually tasted and bottled to capture the subtle variations in flavor. Winning the World's Best Whisky award in London in 2014 really helped sales, as the element of quality drives brand awareness and sales. The Head Distiller feels that building a strong and consistent business foundation is of the utmost importance. In terms of the export supply chain, having experienced partners, traders and distributors in foreign markets is also critical. Building brand awareness takes time and effort, and this means spending time on the ground, attending whisky tasting and trade shows. He feels it is critical for him to be there in person to tell the story of the company, the region and the provenance behind the whisky makes all the difference to spreading the word that then is translated into sales. These are the things that the brand reputation hinges upon. The company have also developed a strong relationship with government trade agency Austrade, who have been very helpful in establishing overseas contacts and setting up export opportunities. With some 16 employees on board and a swag of awards adorning the walls of the tasting room at the distillery, the team can now take more time to experiment and have more fun, invent and innovate. The $\mathrm{KM} / \mathrm{SSCM}$ focus is predominantly centered on relationships and collaborations with stakeholders along the supply chain, as well as paying attention to quality, capacity, sustainability and traceability.

\section{Case 8- 'AbaloneCo'}

Based in South Australia, this aquaculture company is now the biggest abalone operation in the southern hemisphere. With abalone commanding high prices in overseas markets in Asia and North America, this firm's business model is focused not on short term financial outcomes but more on protecting the pristine environment in which they operate. Innovation is key to their operations which are focused on growing abalone in controlled conditions that replicate natural sea bed environments. This includes using artificial waves to continually cleanse the growing environment. After 18 years of operations, recent innovations are driving plans to triple production output over the next three years. Employees are all charged with responsibility for innovation and this has been achieved through improved knowledge of abalone genetics, energy reductions, as well as other quality and efficiency improvements such as agile packing processes. Relationships with customers overseas are well developed and long-term in nature. Besides innovation, management and environmental protection are major strategic drivers. The firm ensures there are multiple growing sites, strict biosecurity measures in place, as well as careful quality control over water, feed and other inputs. The main focus on KM and SSCM involves innovation, sustainability, traceability, provenance, and technology. 
The analysis indicated that KM plays a major role in supporting SSCM across the firms in this study. The areas in which KM contributed the most to SSCM practices within these firms include the following dimensions:

- $\quad$ Strategic focus, strategic planning

- Protecting the reputation and performance of the organization

- Commitment to SSCM practices such as food safety and traceability

- $\quad$ Supporting standards, certification and risk management

- Learning from partners

- Relationships and communication

- Innovation

In terms of strategic focus, KM was found to be a key element in almost all of the firms in this study. Knowledge of markets, competitors and other stakeholders are essential to developing successful business strategies. KM also contributed to innovative business model development for these firms, particularly in terms of emphasizing and supporting SSCM practices and creating value for stakeholders in this manner. KM also contributed heavily in protecting the reputation of these organizations, particularly stressing their commitment to sustainability, quality and innovation in their operations.

KM was a prominent pillar of support for those firms who strategically target overseas competitions as a means of gaining and maintaining a reputation through winning world class category awards. Developing and creating new value is a priority, and KM assists through developing a strong alignment between the business strategy and technology, investment in technology, effective knowledge capture and the benchmarking of competitors. Performance measurement is also an area in which $\mathrm{KM}$, particularly through knowledge integration contributes in these award-winning companies, thus highlighting the importance of proactive management of SSCM that results in business performance.

It was clear that KM contributed heavily to SSCM practices such as food safety, traceability, provenance and maintaining strict biosecurity conditions. This is where standards and certification also play a role, which was heavily supported by KM in all of the organizations studied. All the firms studied worked proactively to improve their social and community impact, and all measured their environmental impact. This was shown to be an area in which the contributions of KM were very significant, particularly in terms of knowledge acquisition, sharing and dissemination.

These firms exhibited a strong customer focus where customer feedback is actively sought and where ideas come from external sources such as buyers and distributors. Collaboration with outside partners was also strongly associated with KM practices of knowledge sharing, highlighting the pivotal role of the customer in all business enterprises. Relationship building and relationship management represented a major thrust for KM practices. KM efforts around risk management, particularly through processes such as knowledge acquisition, knowledge integration and knowledge dissemination engendered a willingness to take calculated risks based on strategic information and led to greater levels of change management and innovation as a result. Overall, innovation capability of these firms was high, and it is clear that the links to KM support were pivotal in maintaining a strong innovation focus and consequent innovation performance.

\begin{tabular}{|c|c|c|c|c|c|c|c|c|}
\hline CASE & $\begin{array}{l}1 \\
5\end{array}$ & 2 & $\begin{array}{l}3 \\
6 \\
6\end{array}$ & 4 & $\begin{array}{l}5 \\
8\end{array}$ & 6 & 7 & 8 \\
\hline $\begin{array}{l}\text { Strategic } \\
\text { orientation/ } \\
\text { values } \\
\text { prominent }\end{array}$ & & 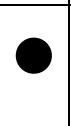 & 0 & & ? & 0 & & \\
\hline $\begin{array}{l}\text { Commitment } \\
\text { to } \\
\text { sustainability } \\
\text { strategy }\end{array}$ & 0 & ( & 0 & 0 & 0 & 0 & 0 & \\
\hline $\begin{array}{l}\text { Balance } \\
\text { between } \\
\text { envir/social/ } \\
\text { economic } \\
\text { goals }\end{array}$ & 0 & 0 & 0 & 0 & 0 & 0 & 0 & $\theta$ \\
\hline $\begin{array}{l}\text { Partner } \\
\text { development } \\
\text { and selection }\end{array}$ & 0 & 0 & 0 & 0 & $\theta$ & 0 & & \\
\hline $\begin{array}{l}\text { Interaction } \\
\text { between SC } \\
\text { partners }\end{array}$ & 0 & O & 0 & 0 & $\theta$ & 0 & & 0 \\
\hline $\begin{array}{l}\text { Practices } \\
\text { used to build } \\
\text { long-term } \\
\text { relationships }\end{array}$ & $\theta$ & 0 & 0 & 0 & 0 & 0 & 0 & (1) \\
\hline $\begin{array}{l}\text { Technical } \\
\text { and logistical } \\
\text { integration } \\
\text { of SC } \\
\text { partners }\end{array}$ & 0 & 0 & O & 0 & O & O & O & 0 \\
\hline $\begin{array}{l}\text { Joint } \\
\text { development } \\
\text { of new tech, }\end{array}$ & 0 & 0 & 0 & 0 & 0 & 0 & $\bigcirc$ & \\
\hline
\end{tabular}




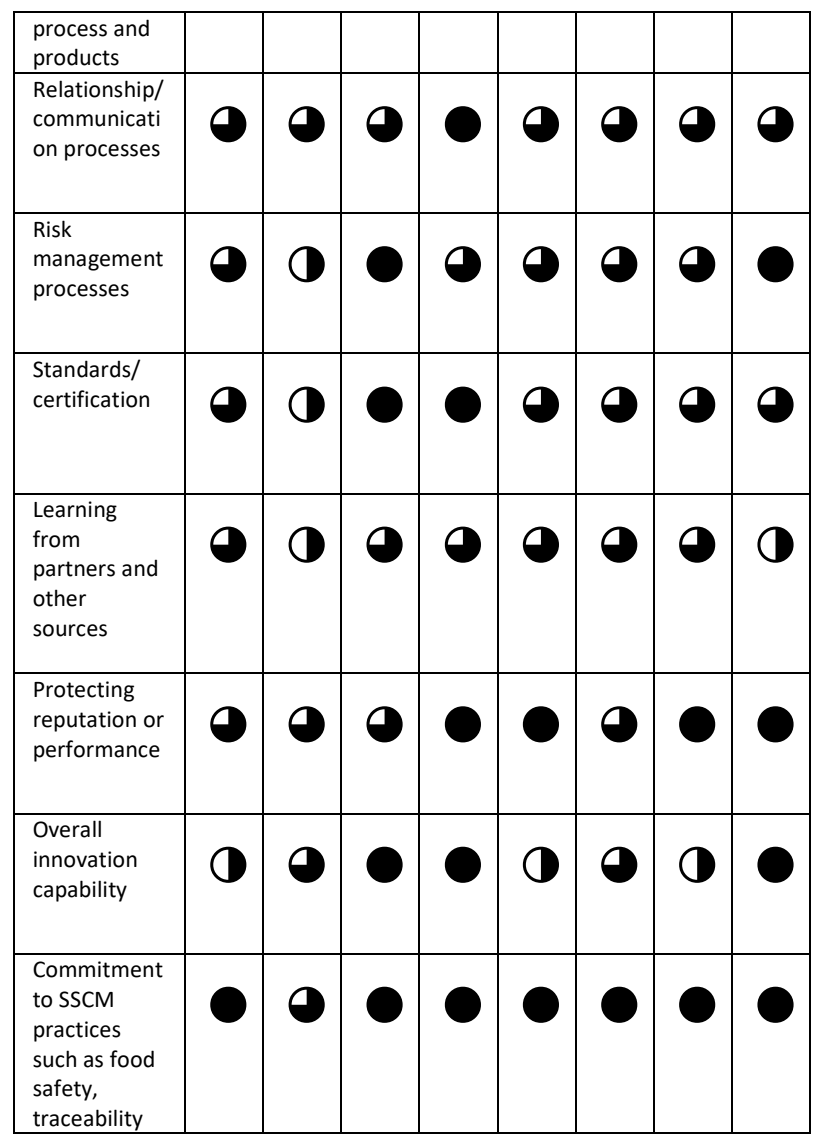

Key: $\bullet$ Very high $\bigcirc$ High $\bigcirc$ Neutral $\bigcirc$ Somewhat $O$ Low

Table 3. Overview of KM contributions across SSCM practices

Areas in which KM did not appear to make a significant contribution to the firms in the study included:

- Joint development of new technology, processes and products

- Technical and logistical integration of supply chain partners

- Balancing economic, environmental and social goals

While collaboration was strong in terms of building and maintaining relationships with customers, buyers and distributors, partnering with SC members to create new technology, products and processes was not a significant feature in these companies. This may be a result of the nature of the businesses who are in the food and beverage export industry; it might be that were they involved in manufacturing to a greater extent, this aspect of SSCM practice might be more fully developed. Similarly, technical and logistical integration of supply chain partners was not a major focus of KM or SSCM practice, and this might reflect the nature of the food and beverage export supply chain, which would be less complex than others. An unexpected finding from the research was that on the whole, these best practice exporters from Australia did not perform particularly well in terms of balancing economic, environmental and social goals. Despite KM efforts to support SSCM, most of these firms still displayed a predominant economic focus with regard to SCM, at the expense of environmental and social concerns. Clearly more research is warranted in this area.

\section{Conclusion}

This exploratory research indicates that there is considerable potential for KM to contribute to value and competitive advantage through supporting various SSCM practices. It is good to see that KM supports a strategic focus within these organizations; as Baumgartner and Rauter [58] suggest, the lack of a strategic orientation in areas such as corporate sustainability is the reason for a lack of progress in the field. They suggest that the introduction of strategic management into the corporate sustainability arena will enable firms to create more business and social value. KM can make substantial contributions to collaboration between supply chain partners and other stakeholders; as Van Hoef and Thiell [59] suggest, collaboration for SSCM may support interorganizational dynamics by growing knowledge absorption capacity and problem solving ability. Collaboration between buyers and suppliers can also enhance social performance and build more socially responsible supply chains [60], so this a major area for future KM efforts. Finally, Oelze et. al. [61] have identified organizational learning as a significant factor for successful implementation of SSCM, which could be another area of fruitful research endeavor. Overall there is a lack of substantive research in this area, and so further studies across larger samples and different types of supply chains may shed further light on the ways in which the management of knowledge can add value to SSCM.

\section{References}

[1] Carter, C.R., and Dale S. Rogers. (2008). A Framework of Sustainable Supply Chain Management: Moving toward New Theory. International Journal of Physical Distribution \& Logistics Management, 38(5), 360 - 387.

[2] Escanciano, C., \& Leticia Santos-Vijande, M. (2014). Implementation of ISO-22000 in Spain: obstacles and key benefits. British Food Journal, 116(10), 1581-1599.

[3] Wognum, P. N., Bremmers, H., Trienekens, J. H., van der Vorst, J. G., \& Bloemhof, J. M. (2011). Systems for 
sustainability and transparency of food supply chainsCurrent status and challenges. Advanced Engineering Informatics, 25(1), 65-76.

[4] Grunert, K. G., Hieke, S., \& Wills, J. (2014). Sustainability labels on food products: Consumer motivation, understanding and use. Food Policy, 44, 177189.

[5] Government of Australia. Department of Industry, Innovation and Science. https://industry.gov.au/industry/IndustrySectors/FoodManu facturingIndustry/Pages/About.aspx

viewed 14 April 2018.

[6] Hammervoll, T. (2009). Value-Creation Logic in Supply Chain Relationships. Journal of Business-to-Business Marketing, 16(3), pp. 220-241.

[7] Barney, J. B. (2012), Purchasing, Supply Chain Management and Sustained Competitive Advantage: The Relevance of Resource-based Theory. Journal of Supply Chain Management, 48, pp. 3-6.

[8] Melnyk, S.A., Lummus, R.R., Vokurka, R.J., Burns, L. and Sandor, J. (2009). Mapping the future of supply chain management: a Delphi study. International Journal of Production Research, 47(16), pp. 4629-4653.

[9] Von Massow, M. and Canbolat, M. (2014). A strategic decision framework for a value-added supply chain. International Journal of Production Research, 52(7), pp. 1940-1955

[10] Allesina, S., Azzi, A., Battini, D. and Regattieri, A. (2010). Performance measurement in supply chains: new network analysis and entropic indexes, International Journal of Production Research, 48(8), pp. 2297-2321.

[11] Baldwin, R. and Lopez-Gonzalez, J. (2015). Supplychain Trade: A Portrait of Global Patterns and Several Testable Hypotheses. The World Economy, 38(11), pp. 1682-1721.

[12] Babin, B. J. and James, K. W. (2010). A brief retrospective and introspective on value. European Business Review, 22(5), pp. 471-478.

[13] Tate, W., Ellram, L. and Kirchoff, J. (2010). Corporate Social Responsibility Reports: A Thematic Analysis Related to Supply Chain Management. Journal of Supply Chain Management, 46(1), 19-44.

[14] Simchi-Levi, D., Kaminsky, P. \& Simchi-Levi, E. (2011). Designing and Managing the Supply Chain. McGraw-Hill, Boston.

[15] Ratan, S. R. A., Sekhari, A., Rahman, M., \& Bouras, A. A. (2010). Sustainable Supply Chain Management: State of the Art. SKIMA 2010, 193.

[16] Seuring, S., \& Müller, M. (2008). From a literature review to a conceptual framework for sustainable supply chain management. Journal of cleaner production, 16(15), 1699-1710.

[17] Teuteberg, F., \& Wittstruck, D. (2010). A systematic review of sustainable supply chain management. Multikonferenz. Wirtschaftsinformatik 2010, 203.

[18] Markley, M. J., \& Davis, L. (2007). Exploring future competitive advantage through sustainable supply chains. International Journal of Physical Distribution \& Logistics Management, 37(9), 763-774.
[19] Carter, C. R., \& Liane Easton, P. (2011). Sustainable supply chain management: evolution and future directions. International journal of physical distribution \& logistics management, 41(1), 46-62.

[20] Elkington, J. (1998). Partnerships from cannibals with forks: The triple bottom line of 21st-century business. Environmental Quality Management, 8(1), 37-51. [21] Peloza, J. and Shang, J. (2011). How can corporate social responsibility activities create value for stakeholders? A systematic review. Journal of the Academy of Marketing Sciences, 39, 117-135.

[22] Ketchen Jr, D. J., \& Hult, G. T. M. (2007). Bridging organization theory and supply chain management: The case of best value supply chains. Journal of operations management, 25(2), 573-580.

[23] Ninlawan, C., Seksan, P., Tossapol, K., \& Pilada, W. (2010, March). The implementation of green supply chain management practices in electronics industry. In Proceedings of the international multiconference of engineers and computer scientists (Vol. 3, pp. 17-19).

[24] Azevedo, S. G., Carvalho, H., \& Machado, V. C. (2011). The influence of green practices on supply chain performance: a case study approach. Transportation research part E: logistics and transportation review, 47(6), 850-871.

[25] Walker, H., \& Brammer, S. (2009). Sustainable procurement in the United Kingdom public sector. Supply Chain Management: An International Journal, 14(2), 128137.

[26] Sroufe, R. and Drake, M. (2010). Measuring the Social Dimension of the Triple Bottom Line: An

Industry Study. Paper presented at APICS International Conference, 2010.

[27] Closs, D., C. Speier, C. and Meacham, N. (2011). Sustainability to support end-to-end value chains:

the role of supply chain management. Journal of the Academy of Marketing Science, 39(1), 101-

116.

[28] Awaysheh, A. and R. D. Klassen (2010). The impact of supply chain structure on the use of supplier

socially responsible practices. International Journal of Operations \& Production Management,

30(12), 1246-1268.

[29] 2010 Prasad, S. and Tata, J. (2010). Micro-Enterprise Supply Chain Management in Developing Countries.

Journal of Advances in Management Research, 7(1), 8- 31. [30] Hall, J and Matos,S. (2010). Incorporating impoverished communities in sustainable supply chains.

International Journal of Physical Distribution and Logistics Management, 40(1/2), 124-147.

[31] Pagell, M. and Wu, Z. (2016). Building a more complete theory of sustainable supply chain management using case studies of 10 exemplars. Journal of Supply Chain Management 45(2), 37-56.

[32] Markman, G. D., \& Krause, D. (2016). Theory building surrounding sustainable supply chain management: Assessing what we know, exploring where to go. Journal of supply chain management, 52(2), 3-10

[33] Montabon, F., Pagell, M., \& Wu, Z. (2016). Making sustainability sustainable. Journal of Supply Chain Management, 52(2), 11-27. 
[34] Hult, G.T.M., Ketchen, D., Cavusgil, S.T. \& Calantone, R. (2006). Knowledge as a strategic resource in supply chains, Journal of Operations Management 24, pp. 458-475. [35] Samuel, K. E., Goury, M. L., Gunasekaran, A., \& Spalanzani, A. (2011). Knowledge management in supply chain: An empirical study from France. The Journal of Strategic Information Systems, 20(3), pp. 283-306.

[36] Bhosale, V.A., and Kant, R. (2016). "Metadata analysis of knowledge management in supply chain: investigating the past and predicting the future." Business Process Management Journal 22(1), pp.140-172.

[37] Marra, M., Ho, W. and Edwards, J. (2012). "Supply chain knowledge management: A literature review." Expert systems with applications 39 (5), pp. 6103-6110.

[38] Collins, J., Worthington, W., Reyes, P and Romero, M. (2010),"Knowledge management,supply chain technologies, and firm performance", Management Research Review, 33(10), pp. $947-960$.

[39] Pan, Y., Liang, D., Ma, X. and Wang, H. (2013). “A new value stream mapping technique based on material flow, information flow and knowledge flow", Applied Mechanics and Materials, Vols. 397-400, pp 8-11.

[40] Yang, J. (2013) Harnessing value in knowledge management for performance in buyer-supplier collaboration, International Journal of Production Research, 51(7), pp. 1984-1991.

[41] Cai, S., Goh, M., de Souza, R. and Li, G.(2013) "Knowledge sharing in collaborative supply chains: twin effects of trust and power", International Journal of Production Research, 51(7), pp. 2060-2076.

[42] Scheuermann, A., \& Leukel, J. (2014). Supply chain management ontology from an ontology engineering perspective. Computers in Industry, 65(6), pp. 913-923.

[43] Desouza, K., Chattaraj, A. and Kraft, G. (2003),"Supply chain perspectives to knowledge management: research propositions", Journal of Knowledge Management, 7(3), pp. 129-138.

[44] Cao, M., Vonderembse, M., Zhang, Q. and RaguNathan, T.S. (2010). Supply chain collaboration: conceptualisation and instrument development, International Journal of Production Research, 48(22), pp. 6613-6635.

[45] Jayaram, J \& Pathak, S. (2013) A holistic view of knowledge integration in collaborative supply chains, International Journal of Production Research, 51(7), pp. 1958-1972.

[46] Armstrong, C. and Shimizu, K. (2007), "A Review of Approaches to Empirical Research on the Resource Based View of the Firm", Journal of Management, 33(6), pp. 959989.

[47] Lockett, A., Thompson, S. and Morgenstern, U. (2009), "The development of the resource-based view of the firm: A critical approach", International Journal of Management Reviews, 11(1), pp. 9-28.

[48] Wernerfelt, B. (1984), The Resource-Based View of the Firm, Strategic Management Journal, 5(2), pp. 171-80.

[49] Barney, J. (1996), "The Resource-Based Theory of the Firm", Organization Science, 7(5), pp. 469-76.

[50] Barney, J. (1991), "Firm Resources and Sustained Competitive Advantage", Journal of Management, 17(1), pp. 99-119.
[51] Grant, R.M. (1996). Toward a knowledge-based theory of the firm. Strategic Management Journal, 17, pp. 109-122. [52] Conner, K.R. and Prahalad, C.K., 1996. A resourcebased theory of the firm: Knowledge versus opportunism. Organization science, 7(5), pp.477-501.

[53] Kogut, B. and Zander, U., 1992. Knowledge of the firm, combinative capabilities, and the replication of technology. Organization science, 3(3), pp.383-397.

[54] Yin, R.K. (2014). Case study research: design and methods, $5^{\text {th }}$ ed., Sage, Thousand Oaks.

[55] Miles, M. B., \& Huberman, A. M. (1994). Qualitative data analysis: An expanded sourcebook. Sage.

[56] Merriam, S. (1998). Qualitative research and case study applications in education. Jossey Bass, San Francisco. [57] Beske, P., Land, A., \& Seuring, S. (2014). Sustainable supply chain management practices and dynamic capabilities in the food industry: A critical analysis of the literature. International Journal of Production Economics, 152, 131-143.

[58] Baumgartner, R. \& Rauter, R. (2017). Strategic perspectives of corporate sustainability management to develop a sustainable organization. Journal of Cleaner Production, 140, 81-92.

[59] Van Hoof, B. \& Thiell, M. (2014). Collaborative capacity for sustainable supply chain management: small and medium enterprises in Mexico. Journal of Cleaner Production, 67, 239-248.

[60] Sancha, C., Gimenez, C. \& Sierra, V. (2016). Achieving a socially responsible supply chain through assessment and collaboration. Journal of Cleaner Production, 112, 19341947.

[61] Oelze, N., Hoejmose, S., Habisch, A. \& Millington, A. (2016). Sustainable Development in Supply Chain Management: The Role of Organizational Learning for Policy Implementation. Business Strategy and the Environment, 25, 241-260. 